This item was submitted to Loughborough's Research Repository by the author.

Items in Figshare are protected by copyright, with all rights reserved, unless otherwise indicated.

\title{
Internationalization of small family firms: the influence of family from a socioemotional wealth perspective
}

PLEASE CITE THE PUBLISHED VERSION

http://dx.doi.org/10.1002/tie.21729

\section{PUBLISHER}

(c) Wiley Periodicals, Inc

\section{VERSION}

VoR (Version of Record)

\section{PUBLISHER STATEMENT}

This work is made available according to the conditions of the Creative Commons Attribution-NonCommercialNoDerivatives 4.0 International (CC BY-NC-ND 4.0) licence. Full details of this licence are available at: https://creativecommons.org/licenses/by-nc-nd/4.0/

\section{LICENCE}

CC BY-NC-ND 4.0

\section{REPOSITORY RECORD}

Scholes, Louise, Michael Mustafa, and Stephen Chen. 2019. "Internationalization of Small Family Firms: The Influence of Family from a Socioemotional Wealth Perspective”. figshare. https://hdl.handle.net/2134/19960. 


\section{Internationalisation of Small Family Firms: The Influence of Family from a Socioemotional Wealth Perspective}

\section{Introduction}

The growing desire to understand internationalisation in family firms suggests a need to understand the influence of family on the internationalisation choices and consequences. Ever intensifying globalisation, fierce worldwide competition, technological developments and new growth prospects beyond national borders have recently been identified as drivers of firm internationalisation in general (Geringer et al., 2000). Internationalisation can be of particular importance to any firm operating in small countries with a small consumer base and to family firms (Arregle et al., 2012). Researchers of family firms have recognised that internationalisation provides family firms with fruitful growth opportunities, give succeeding generations' employment opportunities, increasing performance and ensuring continuity (Arregle et al., 2012; Claver et al., 2009; Fernández and Nieto, 2005; Sciascia et al., 2012).

Empirical evidence on this question of family firm internationalisation however remains far from conclusive. Regarding the actual process of internationalisation, researchers suggest that family firms typically internationalise in slow and cautious manner in line with the Uppsala stage model (Claver et al., 2008; Graves and Thomas, 2004, 2008). Recent evidence however, has suggested that family firms may internationalise rapidly (Kontinen and Ojala, 2012; Mustafa et al., 2013). Consequently, family ownership and involvement has been identified as either positively or negatively effecting internationalisation activities (Cerrato and Piva, 2012; Fernandez and Nieto, 2006; Zahra, 2003).

Despite the growing body of knowledge on family firm internationalisation, the field continues to remain young and thus there is still considerable room, especially regarding any negative effects of family firm characteristics (Kontinen and Ojala, 2010). Existing studies in this area exclusively focus on either family control and influence (e.g., Sciascia et al., 2012b), social capital (e.g., Kontinen and Ojala, 2012b) or the influence of incoming generations (Fernández and Nieto, 2005) and the experiences of larger established family firms or SMEs in large Western economies (see Graves \& Thomas, 2006; Kontinen \& Ojala, 2010b; 2011). 
This study focuses on the internationalisation of small family-owned firms in Singapore. Small family-owned and managed firms continue to form much of the backbone of the Singaporean economy (Chew and Chew, 2008; Yeung, 2006) and account for up to 92 percent of total establishments, contribute to one-third of GDP, and account for nearly 50 percent of employment (Chew and Chew, 2008). Not only are such firms key players in the domestic economy, they are also emerging as key players throughout the South-east Asia region (Sim, 2006; Yeung, 2000; 2006). However, their size, operating practices and strong concentration of family ownership, often results in a number of internationalisation challenges, despite continued support from the Singaporean government (Chew and Chew, 2008). Therefore, understanding the internationalisation process of these firms can help inform managers and policymakers on formulating appropriate strategies to stimulate the process.

The existing literature on Singapore family firms and their internationalisation continues to remain limited. Several scholars have investigated the strategies of family firms, often emphasising the fact that strong cultural drivers such as Confucian values can restrict the development of such firms in the long-run (Tasng, 2001). A lack of sufficient human capital, inability to capture the learning benefits from internationalisation and conservative organisational cultures have been identified as the typical internationalisation barriers (Mustafa et al., 2013; Tsang, 2001; Tsui-Auch, 2004; Yeung, 1999). A further limitation of such studies is that they tended to focus mostly on larger and semi-professionalised family firms and more specifically Chinese Family Business (see Tsang, 2002; Yeung, 2005). Additionally, such studies have not specifically considered factors relating to the SEW resulting from family ownership where issues arising from family members emotional attachment and identification with the firm and the subsequent effect this has on the internationalisation behaviour of the organisation, along with the experiences of smaller family firms from non-Western contexts has been largely neglected by the existing literature.

A model for the internationalisation of family firms, based on the revised Uppsala model, has recently been proposed by Pukall and Calabro (2013). This integrates the relatively new concept of SEW (Berrone et al. 2012) with the revised Uppsala model (Johanson and Valne, 2009). This article takes an exploratory approach to theory development and explores the role of SEW in developing and shaping internationalisation behaviour. Specifically we seek to address the following three research questions: 
RQ1: How do small family firms internationalise?

RQ2: Which family-specific features impact the internationalisation process of small family firms?

RQ3: How do family-specific features impact the internationalisation process of small family firms?

Applying this new approach we address some of the gaps in the literature by synthesizing ideas from the socio-emotional wealth perspective (SEW), networking, and the resource-based view of the firm (RBV) to examine the internationalisation of small family firms. By combining SEW with networking (two social/cultural phenomena), with internationalisation (an economic phenomenon) we are also addressing the call for more inclusion of the socio-cultural context in research on family firms (Thornton et al., 2011). Empirical data was drawn from six small internationally active family firms from Singapore. In each of the case studies, the issues of SEW in the shape of trust and harmony and the subsequent network relationships and availability of resources are explored. The article is structured as follows. Firstly, we explore the literature on family firm internationalisation, SEW and RBV. This is followed by the methodology. The results and discussion relate the findings to theoretical developments. Finally, our paper concludes by outlining the theoretical and managerial implications of our findings and areas for future research.

\section{Socio-emotional wealth and internationalisation of family firms}

By capturing and structuring the intertwinement of the owning family with the business, the concept of socioeconomic wealth (SEW) has rapidly emerged as a leading theoretical lens to explain the behaviour of family firms (Berrone et al., 2012). According to Berrone et al. (2012), SEW represents the "single most important feature of a family firm's essence that separates it from other organisational forms". Family firm owners use SEW as one of their central reference points, if not the only one (Gómez-Mejía et al., 2007). Broadly, SEW refers to non-economic rewards that family owners may derive from their businesses (Gomez-Mejia et al., 2007), including their emotional connections to the firm, the family values instilled in the family business culture, and their altruistic behavior (Gomez-Mejia et al., 2011). The SEW perspective 
suggests that family owners gain from the socio-emotional aspect of the business (Gomez-Mejia et al., 2007). Berrone et al. (2012), suggested that the SEW endowment is composed by five dimensions, which are "Family influence and control," "Identification with the firm," "Bonding social ties," "Emotional attachment with the firm," and "Renewal of family ties through dynastic succession”.

SEW has often been portrayed as something positive for family firms but it has can also have a dark side. By serving as a driver for self-serving behaviours it can, for example, lead to negative PSE (proactive stakeholder engagement) (Kellermanns et al., 2012). SEW will potentially effect whether family firms internationalise at all and, if they do, to what extent. In term of the Uppsala model the extent of internationalization is described in terms of stages. In stage 1 firms typically begin to internationalisation with indirect entry modes such as exports. In stage 2, internationalisation is through agents. As firms start to learn how to deal with the customers or suppliers in a particular target country, founding of an overseas sales subsidiary (stages 3 ) and later their own production facility (stage 4) may follow.

Family harmony is closely related to some of the constructs identified by Berrone (2012) and as such is a part of the SEW concept. It is most obviously linked to the bonding social ties as without harmony bonding social ties will be weakened and emotional attachment to the firm reduced. Family firms have often been described as fertile grounds for conflict (Kellermanns and Eddleston, 2004). As such the desire to maintain family harmony remains one of the key longterm objectives of family firms (Malone, 1989; Sharma and Manikutty, 2005). Recently, Graves and Thomas (2008) suggested that family harmony can influence the internationalisation behaviour of family firms. They found specifically that it could influence funding for internationalisation and growth where harmony led to enhanced funds for growth (through reinvestment of dividends) and conflict led to reduced funds for growth (through changes in equity ownership as a result of family members leaving the business).

Strategic efforts to internationalise could result in either enhancement of family harmony or disruption of family harmony. If disruption occurs with loss of SEW will this mean that they withdraw from this particular strategy in order to restore harmony? Family firms may thus favour strategies that enhance or at least preserve their SEW from a harmony perspective. What are these strategies? 
Trust is also related to SEW through the bonding social ties of family which are primarily built on trust. Trust may capture the basis for some of the inherent strengths, weaknesses, and behaviours of small family firms. Trust refers to an individual's willingness to be vulnerable to another party and the expectation that an exchange partner will not behave opportunistically even when such behaviour cannot be detected (Mayer et al., 1995). Research suggests small family firms may be particularly capable of capitalizing on trust (i.e., Cruz et al., 2010). For example, long-term family relationships can breed trust, which reduces the amount of monitoring and incentives required to solve agency problems (Chrisman et al., 2007). This is of particular relevance to small family firms whom often rely on their family and co-ethnic networks for internationalisation (Erderner and Shapiro, 2005; Mustafa and Chen, 2010; Tsang, 2002).

However, trust also has a dark side, wherein it can lead to blind faith, amoral familiarism, and complacency (Steier and Muethel, 2014; Sundaramurthy, 2008). While the importance of trust in internationalisation has been acknowledged by scholars, we see a further need to better understand the issue of trust in small family firms. From an organisational behaviour perspective trust has been shown to facilitate business as well as familial and social relationships (Pearson and Carr, 2011). Family businesses are also more inclined to enter into exchange relationships with other family businesses, especially when internationalising (Karra et al., 2006).

Efforts to internationalise may be more likely to succeed where there are high levels of trust between the family business and 'agents' abroad such as other family members, but is this as true for exporting as it is for building manufacturing facilities abroad? Variations in the levels of trust may therefore effect the levels of SEW which in turn will affect internationalisation

efforts. Despite the fact that trust has been shown to be a facilitator of businesses, the extent of trust in small family firms and the effect this has on the extent of internationalisation is still largely unexplored. Family firms may thus favour strategies that involve high levels of trust in order to preserve their SEW, which in turn may have a positive or negative effect on internationalisation efforts.

\section{Networks, resources, capabilities and internationalisation of family firms}


One possible consequence of harmony and trust is the effect they will have on the ability of a family firm to develop networks and to build resources, both of which will subsequently enhance their ability to internationalize, which is especially important for small firms. The recently revised Uppsala model of internationalisation gives recognition to the importance of networks (Johanson and Vahlne, 2009). Networks will make it possible to identify and exploit (or create) opportunities that will have impact on which entry mode is chosen and which geographic location is chosen, providing the necessary resources are also available.

There is much evidence in the literature on the importance of networking and internationalisation of firms in general (Coviello and Munro, 1995). From a family firm perspective however studies tend to focus on the negative influence of family and have shown how the networking behaviour of family firms negatively affects their internationalisation (Thomas and Graves, 2006; 2008; Kontinen and Ojala, 2010; 2011a; 2011b). For instance, family firms are less likely to engage in networking with other businesses than non-family SMEs (Thomas and Graves, 2006; Mustafa and Chen, 2010) and often lack bridging social-capital necessary for internationalisation (Kontinen and Ojala, 2011b). Fernández and Nieto (2005) identified lack of foreign contacts or export experience, knowledge about foreign markets, as well as adequate personnel, as factors that dissuade family firms from internationalising.

Form an RBV perspective a firm cannot expand without the necessary resources and capabilities and the lack of resource at firm level can be partly compensated for by using networks. Networking (social capital) is thus a valuable resource but other resources are also necessary if internationalisation is to take place namely human and financial capital which can both be influenced by harmony and trust. An unwillingness to accept outside expertise (human capital) and a lack of financial resources (financial capital) have already been identified as limiting the internationalisation efforts of family firms (Claver et al., 2008; 2009; Casillas and Acedo, 2005; Gallo and Pont, 1996; Graves and Thomas, 2006).

The article explores the possibility that harmony and trust, which are embedded in the behavioural theory of SEW, will influence the extent of networking and the development of resources necessary for internationalization.

\section{Methodology}


In order to explore our underlying research questions a qualitative research design was chosen. As suggested by Eisenhardt (1989) and Yin (2003), a multiple case study approach allows for in-depth investigations of specific phenomena while also permitting researchers to explain cause-and-effect relationships. The use of replication logic allowed the researchers to identify and explore similarities and differences among cases (Eisenhardt, 1989; Yin, 2003). Our approach also permitted us to understand the internationalisation of small family firms as perceived by individuals which were present in the situation. Our approach is also consistent with prior researchers who have used a multiple case study method to develop rich insights into the internationalisation process of family firms (see Graves and Thomas, 2008; Kontinen and Ojala. 2010b) and has been described as an important way to progress the field of family scholarship (De Massis and Kotlar, 2014).

\section{Case Selection}

Data was drawn from six internationally active small family firms from Singapore. Singapore was chosen because it is representative of a small open economy with a very limited domestic market and one were small family firms proliferate (OECD, 1997). According to Sapienza et al. (2006), the ability of firms to guarantee long-term continuity in such contexts is often dependent on a successful internationalisation strategy. Additionally, the Singaporean government over the past two decades has been actively promoting the modernisation and in particular the internationalisation of SME businesses through a number of policy initiatives (Yeung, 1999).

The firms included in the inquiry were selected on the basis of their internationalisation activities and their size. Thus the sampling strategy was purposeful. The following criteria was used to identify potential case firms: (i) the firm had to have fewer than 50 employees in Singapore, hence fulfilling the criteria of the Singaporean government of a small sized enterprise, (ii) be a family firm in that it have majority family-ownership and control and have members of more than one generation actively involved with the business, and (iii) the firm had to be engaged in cross-border or international activities. Using the lead author's knowledge, a total of ten potential case companies matching the above criteria were identified and contacted. The final selection of the cases was carried out by considering, not only to the variety of sectors in which the firms operated, but also any difficulties and success the firms encountered during 
their internationalisation. Table 1 provides a summary of the key characteristics of the case firms.

\section{INSERT TABLE 1 HERE}

\section{Data collection and analysis}

The individual small family firm was considered as the unit of analysis. In investigating their internationalisation, we chose to conduct interviews with those persons who had most indepth knowledge concerning internationalisation of the case firms. This included founders (where possible) or current family owners/managers. Additionally key informants such as family members in managerial positions and non-family employees such as administrators or managers we also interviewed. All interviews were semi-structured, with an interview protocol being used to facilitate some level of standardization and cross-case analysis (Eisenhardt, 1989). All interviews were conducted in English and followed a protocol which was continuously adjusted in relation to the themes that emerged from prior interviews. Each interview lasted approximately 45 to 80 minutes in duration and was digitally recorded and transcribed verbatim. During the second listening, correspondence between the recorded and the transcribed data was ensured. Complete case reports were sent back to the interviewees and firm owners, and any inaccuracies they noticed were corrected on the basis of their comments.

A major strength of a case study data collection is the opportunity to use different sources of evidence (Yin, 2003). In addition to the semi-structured interviews, secondary data, such as web pages, company reports, financial records, meeting minutes, and brochures were also utilized. This secondary data helped the researchers to understand the history and the products of each firms, form detailed case histories, and to understand the circumstances behind certain events during internationalisation. This data was also utilised to triangulate with the information given by the informants.

\section{Data analysis}

Coding was structured around the research questions and was adjusted as new themes emerged. Data was analysed in accordance with the techniques described by Miles and Huberman (1994). Firstly, a detailed case history for each case firm was compiled. Secondly, all 
relevant data were collected and placed in matrices, graphs, charts, networks, and in tables. Finally, the SEW specific features that appeared to have significance were identified. At this stage, regularity, patterns, explanations, and causalities relating to the phenomena were noted.

\section{Empirical analysis and discussion}

\section{The Internationalisation Process}

Our study seeks to explore the extent to which small Singaporean family firms internationalised, why and how it started and how they continued their international operations (see table 2). All case firms examined had long-term established domestic business operations before internationalising. Consequently their internationalisation can be characterised as slow and incremental. Four of the case firms (A, B, C and D) took between 15 and 21 years before to achieve their first international sale. For the remaining two case firms (D and F) internationalisation occurred within 12 years from their inception. The internationalisation of firms A, B and D was carefully planned and in no way ad-hoc as suggested by the literature (Johanson and Vahlne, 1977; Johanson and Wiedersheim, 1975). In cases C, D and F, internationalisation was ad hoc and motivated by unsolicited orders from family abroad (D and F) or through a chance encounter with sales representatives (C and F).

Internationalisation in all cases was financed initially through family-pooled funds and familial equity either locally or from abroad (A, B, C and F), commercial loans (A, B, C and E) and subsequently from internally generated revenue (A, B, D and F). In only two cases ( $\mathrm{E}$ and F) was there an attempt by the family owners to bring external equity to help finance internationalisation. Given the considerable financial commitments by immediate and extended family, such family members and to a lesser degree close associates abroad played critical roles in the case firms internationalisation process. Often these roles would include identifying opportunities in new and established foreign markets (all cases), facilitating and planning entry by managing foreign market operations personally (A, B and C) or providing links to agents and firms in foreign markets (A, C, E and F) or managing operations abroad specifically (all case firms).

With the exception of firm F, internationalisation in all cases began with direct exporting modes. Subsequently, only two cases (E and F) established small scale manufacturing facilities abroad. In the remaining instances, case firms preferred either direct exports (A, B and C) or 
exporting through agents/distributors ( $\mathrm{C}$ and $\mathrm{E}$ ) or entering into small scale and simple alliances primarily with other family firms abroad (A and C). In general, majority of our case firms were exporting products to multiple regional markets. The number of overseas locations ranged from two to seven countries. However, closer analysis of the data reveals most of the case firms' internationalisation activities tend to be concentrated in the South-east Asia region, i.e to countries which are both physically and psychically close.

In all but one case (C), either Indonesia or Malaysia was identified as the first international destination. Only two firms, E and F, had begun to move out of the South-east Asian region into more physically and psychically distant markets such as Australia and New Zealand (E) and Middle-east and U.S.A (F). Finally, all case firms had extended or slightly adapted their current products or services to nearby countries with similar economic and cultural environments. However, beside case firms $\mathrm{E}$ and $\mathrm{F}$, neither of the remaining case firms invested in developing new products specifically for their international customers.

In general our findings suggest that small Singaporean family firms internationalised in stepwise manner adopted a cautious and reluctant approach to internationalisation (Graves and Thomas, 2008; Claver et al., 2009) and internationalised to both physically and psychically close markets (Kontinen and Ojala, 2010b). However we also note the important role that family members, both locally and abroad, played in their internationalisation process.

INSERT TABLE 3 HERE

\section{Influencing factors}

Respondents were asked to indicate how family specific factors affected their firm's abilities to succeed internationally (secondary research question). A thorough analysis of the interviews and case data identified (i) family harmony, (ii) trust in external relationship, (iii) social and business networks, (iv) organisational resources availability and capabilities as family specific features which influenced the internationalisation of small Singaporean family firms. The following section will discuss each of these features and how they constrained the case firms' internationalisation. The results are also summarised in Table 3. 
Harmony: family conflict

Family firms have often been described as fertile grounds for conflict (Kellermanns and Eddleston, 2004). As such the desire to maintain family harmony remains one of the key longterm objectives of family firms (Sharma and Manikutty, 2005). Family harmony, which is closely based on interpersonal trust, can create orderly, stable and socially integrating structures which bind the family together. Recently, Graves and Thomas (2008) suggested that family harmony can influence the internationalisation behaviour of family firms. Among all of our case firms, there was a strong desire to seek strategies and actions to ensure trust between family member and to avoided conflict. Moreover, our data suggests that the pursuit to maintain family harmony affected the case firms abilities to exploit international opportunities in several ways.

Respondents from the case firms (A, B, C and D) all indicated that maintaining familial harmony was a guiding principal which affected how strategic decisions regarding internationalisation were made. For instance, both case firms A and C, appeared to be strongly committed to their domestic operations (firm C) or a few select foreign markets (firm A), and were not willing to take excessive risks to develop their firms beyond these markets. The strong domestic focus was in part influenced by these case firms desire to provide continued employment for both immediate and extended family members of the firm. As the owner of firm C commented:

"our key aim is maintain to a harmonious continuity of the firm across generations. In this respect, we must balance current needs with that of future needs..... International growth is risky and poses a challenge to how we maintain future harmony"

Additionally, in cases A, B, C and D were there was generational and extended family member involvement, we observed the managing family preferred to adopt a consultative approach to decision making regarding key actions so that familial harmony could be maintained. According to several respondents from these firms, while such process achieved their aim, they nevertheless slowed down decision making processes resulting in missed international opportunities or the adoption of strategies for the appeasement of others. For instance, in the case firm B, excessive wrangling among family members on how best to enter the Thailand market, meant that the firm was not able to take advantage of a potential lucrative offer with a national brand retailer. Subsequently, the firm had to seek out new entry modes and 
eventually decided on direct exporting as it was according to the owner "the least riskiest option and the only one were everybody could partially agree on".

Furthermore, trying to maintain family harmony also influenced the families’ willingness to commit financial resources for internationalisation. Firms (A, B, E) in this study all indicated that pooled funds of family members both in Singapore and abroad and internally generated revenue were the main sources of financial capital for internationalisation. Accordingly, in such cases, family managers were not willing to risk the family members' investments in the firm and hence a cautious approach was adopted to how and such funds could be used for internationalisation. For instance, in the case of firm E, the family had initially planned to enter the Burmese market through direct exporting in 2009, were stalled because poor financial performances between 2005-2008. This poor performance had caused considerable tension between several family members as they lost a considerable amount of their initial investment in the firm. Rather than risk further tensions, the family agreed to abandon future attempts at expanding into the market and instead focus on domestic operations.

In other cases however (eg A and B), the owning family could only maintain harmony by pruning the family tree. However, in depth interviews revealed that by doing so, these case firms experienced a sudden loss of valuable financial and non-financial resources necessary for internationalisation. For example, in the case of firm A, continued in-fighting between families over how to grow the Indonesian market resulted in three key family managers abandoning their stake in the business. Not only did firm A lose financial capital, but it also lost market knowledge and key relationships in the market. In general, our case findings suggest that familial harmony is a long-term goal for small Singaporean family firms. However, in trying to maintain familial harmony, small family firms may run the risk of adopting a conservative strategy as to how their resources are deployed for internationalisation.

\section{Trust: lack of trust in external relationships}

From a relational perspective, trust and the ability to form long-term relationships represents an important element of family firms cultures (Abdellatif et al. 2010, Calabrò and Mussolino, 2011, Kontinen \& Ojala, 2011). In fact, several researchers have claimed that mutual trust underlies the governance structures and process of many family firms (i.e., Corbetta and Salvato, 2004; Eddleston et al., 2010). The small nature and the strong bonds between family 
members can often enhance the degree of trust within small family firms. Research suggests that the strong values and a high long-term commitment level found in many family firms, inspires trust based relationships which should make their internationalisation process easier (Kontinen and Ojala, 2010). While family firms in our study indicated the importance of trust in their internationalisation process, they were also quick to highlight the importance of both excessive trust between family members as well as distrust of outsiders with respect to their internationalisation activities.

Amongst our case firms, values such honesty, trust and trustworthiness were identified by respondents as core principals by which the case firms lived by and how they conducted their commercial transactions. For several of case firms (A, B, C and E), trust was afforded solely to family members and close associates. Consequently in these cases, the firms preferred to largely deal with selected individuals or organisations in foreign markets with which they either had close blood ties (A, C and E) or long-established trading relationships, suggesting a distrust of outsiders. In the case of firm E, family members or close friends abroad were regularly used as agents abroad. Furthermore, family members were also willing to travel abroad to places like China so that the firm could establish a trading store there. However, further examination of case data and interviews also indicated that when such individuals were not available in foreign markets, the case firms often did not take the risk of dealing with individuals or firms they did not know. For instance in both case firms A and C, the family was willing to either totally abandon or scale back development of particular markets until a suitable family member was available. As the marketing manager of firm C explained:

"Being trustworthy and honest is a core family value. Unfortunately, we cannot always find other companies abroad with similar values. When this is not possible, we prefer to rely on people we can trust (family etc) abroad"

A lack of trust of outsider was further identified by some respondents as one of the main reasons why their firms (A, B and C) were not able to capture the learning benefits associated with internationalisation. For instance, in the case of firm $\mathrm{A}$, all internationalisation related activities were carried out by immediate or extended family members only. Thus, when several family members left, firm A did not seek to promote or hire non-family members into their roles. Subsequently, firm A had to scale back its exporting activity to Indonesia and Brunei, as they did 
not poses sufficient market knowledge. Similarly, in the case of firm B, identifying and negotiating with distributors in Vietnam experienced several problems and was only successful after the owner temporarily relocated to Vietnam to oversee the operations personally and a nonfamily marketing manager with experience in the market was hired. The difficulties faced by firm B in this situation were attributed to the family members' personal lack of experience and knowledge about the Vietnamese market and the unwillingness of the family to hire external talent with the necessary knowledge and experience.

Additionally, having too much trust in certain relationships was also identified by respondents as a constraining factor. For instance, in the case of firm C, the family would only deal with local suppliers whom they had a long-standing relationships with, and would rely implicitly on their advice regarding products and material. Placing such high trust in their suppliers however, had a particularly damaging ability on firm C's ability to suddenly change and adapt its products abroad. Furthermore, both cases A and E placed considerable blind faith in extended family members abroad to seek and develop new opportunities, albeit at times with disastrous consequences. For instance, in the case of firm E, the trust placed in the close relative of the owner to arrange sales in China backfired, as the individual used the firms resources to advance his own particular cause. As a result, case firm E experienced a significant setback in entering and developing the Chinese market.

These findings shed further light on the role of trust in influencing the internationalisation process of family firms. Prior research has stressed the importance of trust, especially exploiting the inherent advantages of family firms (Cruz et al., 2010; Mustafa and Chen, 2010; Steier, 2001). Our findings here highlight the dark side of trust or lack of, in family firms. For instance, placing excessive trust in family members can not only lead to opportunistic behaviours abroad, but it might also curtail the development and exploitation of new international markets and opportunities. Similarly, being highly distrustful of outsiders and having an insular outlook may considerably influence the international network selection of small family firms.

\section{Networks: restricted social and business networks}

Prior research has continuously stressed the importance of relationships and networks as crucial for SMEs and family firms as they represent a valuable resource and source of information in foreign markets (Graves and Thomas, 2008; Sharma and Blomstermo, 2003). 
Small family firms can be insular in their associations with others, and this is likely to be reflected in their networking behaviours. Our findings from the case data suggest that small Singaporean family firms tended to restrict themselves to narrow set of social and business networks for their internationalisation. Respondents from our cases indicated that in most instances their firms networks tended to limited to family members (all case), friends (A, B, C, E), close business associates (B and D) or other small family firms (A, C and D). Subsequently, respondents identified that their firms ability of seek and recognise new international opportunities, penetrate existing markets and develop new products and relationships was constrained because the narrow circle of relationships they used for internationalisation. For instance, the manager of firm A expressed how his firm was not able to recognise new opportunities in the Indonesia market for several years because of their continued reliance on a personal friend to develop the market:

"Capturing international customers in Indonesia is somewhat limited for us. We always go through our trusted partner there. There focus is only on a small segment of the market...."

Furthermore, we identified limited efforts by some case firms (A, B, C and D) to move beyond their immediate family circle and social network to seek prospective partners and contacts abroad. Respondents from cases B and C, indicated by focusing on a few key relationships, their firms experienced difficulties in identifying and establishing new relationships in foreign markets. For example in the case of Firm C, relying on small family firms in Philippines to distribute their product meant that the firm missed out on a opportunity to develop new co-operative partnerships in with a large firm retail chain in the country.

The preceding findings support prior research that views the closed networks of family firms as limiting the extent and degree of their internationalisation (Graves and Thomas, 2004; Mustafa et al., 2013). Furthermore, our above findings suggest that a lack networking activity abroad can further limit the potential identification of fruitful new international relationships necessary for continued market development (Graves and Thomas, 2008; Kontinen and Ojala, 2011b; Mustafa et al., 2013). Thus an emphasis on networking activity rather may be critically important in internationalisation efforts of small family firms.

Resources: organisational resource availability and capabilities 
In order grow and develop internationally, small family firms need to develop the necessary organisational and managerial capabilities (Graves and Thomas, 2008; Claver et al., 2008). However, only two firms ( $E$ and F) identified themselves as having developed the necessary organisational and managerial capabilities to pursue their internationalisation strategies. Evidence from the in-depth interviews identified organisational rigidities, in particular inflexibilities in production systems as a major factor which constrained the case firms' ability to successfully penetrate and exploit foreign markets. For instance, in the case of firm B, the use of outdated manufacturing technologies and unwillingness by the owners to invest in updating them, meant that the firm was often slow in responding to changes in international customer demand. Similarly, in the case of firms A, D and E, production was highly geared towards the local market. As a result, there were instances in these cases firms were was insufficient production capacity available to meet international demands. As the production manager of firm E explained;

"our production capacity is limited and often stretched to just meet our domestic demand. We can only export our excess, and in some cases our international orders go unfulfilled..”

Additionally, several of the case firms (A, B, C and D) further identified outdated marketing capabilities (A and B), limited investment in R\&D (A, B and E), human capital, managerial capabilities and organisational learning process (firm A, B and E) as further organisational capabilities that effected their internationalisation. For example, the marketing capabilities of the case firm A were strongly related to the owner or key family member's personal selling initiatives. Thus marketing activities tended to rely exclusively on trusted individuals personal selling abilities, with little use of internet or entrepreneurial marketing techniques. In contrast, firms $\mathrm{E}$ and $\mathrm{F}$ have invested heavily in boosting their marketing capabilities over the past few years, by hiring external non-family managers as marketing managers. These managers designed and implemented a marketing strategy based around trade magazines, radio and internet advertisements, thereby facilitating the firm's abilities to export to physically and psychically distant markets such USA and Australia.

The findings here concur with prior family-firm internationalisation research regarding the lack of organisational and managerial capabilities among family firms (Claver et al., 2009; 
Graves and Thomas, 2004). They also highlight the competing demands placed on family firms i.e the need to maintain family harmony and how a lack of trust regarding outsiders can influence how and why some firms resources and capabilities for internationalisation are ultimately developed and deployed.

The relationships between the four factors are depicted in Figure 1 where trust and harmony are the interlinked SEW factors, networks and resources are the interlinked enablers of internationalisation, and where the left to right flow represents trust/harmony impacting on networks/resources which impact on internationalization. All of the arrows are bi-directional indication influences in both directions. In order to move from the first to the second stage of internationalization a reduction in trust accompanied by less emphasis on family harmony may be necessary.

INSERT FIGURE 1 HERE

\section{Discussion}

The aim of this study was to provide insights into internationalisation of small family firms and the family-specific features of these small firms which affect their internationalisation.

In answering to RQ1 (how do small family firms internationalise?) we found that the majority of firms internationalised using family-pooled funds, commercial loans or internally generated revenue. In the majority of cases internationalisation began with exports and only two cases moved beyond. The two cases who did move beyond exports, established their own manufacturing facilities and did so with the help of external equity. Our findings contribute to the internationalisation of family firms literature, by addressing researchers call for greater attention to be paid in examining the internationalisation processes itself (Kontinen and Ojala, 2010). The findings from this study showed that small Singaporean family firms adopt a stepwise approach to internationalisation which favours both psychically and physically close

countries, thus confirming the earlier findings that family firms follow a sequential internationalization process (Claver et al., 2007; Graves and Thomas, 2008)

With respect to RQ2 (which family-specific features impact the internationalisation process of small family firms?) we found that the most important factors were family harmony, 
trust in internal and external relationships, social and business networks and finally organisational resources availability and capabilities.

In answer to RQ3 (how do family-specific features impact the internationalisation process of small family firms?) we used SEW to explore the relationship between the four important factors and internationalization. Family harmony (enhanced SEW) is more important to a family than internationalisation so has a negative effect on internationalisation. Trust (enhanced SEW) is useful in order to begin the internationalisation process through exporting but then limits the firm's ability to internationalise further. Harmony and trust together influence networks and resources (capabilities), to the extent that limited networks are established yielding limited resources and a negative effect on internationalisation. In order to be able to internationalize further than via exports there may have to be a reduced reliance on trust and willingness for the family to be less harmonious.

Trust has played a critical role in how small Singaporean family firms selected and developed their international networks. Amongst our case firms, we observed a general reluctance to find and establish relationships with non-family partners. Moreover, international relationships tended to be carefully selected and cultivated over a long-period of time and often involved reciprocal arrangements. Such requirements took considerable time and diverted much needed resources of the family away from other activities related to internationalisation.

Additionally, there appeared to be little development of new networks once internationalisation occurred. Instead, most of our case firms tended to stick with their existing relationship, even though at times such relationships bore them little advantages. In fact, research suggests that small family firms may be particularly capable of capitalizing on trust (Cruz et al., 2010; Steier, 2001) as means of encouraging their internationalisation (Calabrò and Mussolino, 2011; Mustafa and Chen, 2010). Contrary to such suggestions, our findings demonstrate that trust can have a particularly constraining effect on how small family firms develop and deploy their resources necessary for internationalisation, through its effect on strategic decision making in such firms.

The findings from our study have several implications for theory.

First, we add to the literature on SEW in the context of its importance for internationalisation of family firms in several ways. Firstly, we identified the particular SEW factors of family harmony and family trust as determining if and to what extent 
internationalisation takes place. Secondly, we confirm that the inclusion of SEW in the model of internationalisation by Pukall and Calabro (2013) is justified but we also suggest that networks are reversibly connected to SEW and that other resources such as human and financial capital are also critical to internationalisation and should be included in the model. Thirdly, we demonstrate that the socio-cultural context is important as economic drivers such as internationalisation do not take place in isolation but rather in the social and cultural context of family and their networks. Moreover, our findings also demonstrate that the socio-cultural context can be particularly important in influencing and shaping family owners perceptions of their SEW endowments.

Secondly, we contribute to the trust-based perspective of family firms by demonstrating its complex interaction with other family specific features (Eddleston et al., 2010). Among our case firms trust was woven through multiple layers of the firms, creating a distinct pattern that embodies its defining features such as family harmony. Preserving such harmony leads to satisfaction in both business and family objectives and often involves avoiding potentially damaging conflicts by trying to reach consensus in decision making. Our case evidence suggest that in order to maintain familial harmony, precluded some of our case firms from investing financial resources for the development of necessary organisational and managerial capabilities necessary for internationalisation. Similarly, we found that dis-harmony, particularly among family members to have disastrous effects on how key resources like market knowledge and learning are accumulated.

Finally, we address recent calls in the literature to better understand the internationalisation of family firms from a network/relational perspective (Pukall and Calabro, 2013). In particular our findings suggest that establishing networks or even contractual relationships with non-family partners may be quite challenging for such firms where understanding and accepting the lack of trust may be especially difficult. Broadly, our finding here is in line with the existing literature on the internationalisation of family firms from Asia highlighting the importance of personal trust based relationships as the backbone of their international activity (Erderner and Shapiro, 2005; Tsang, 2002; Yeung, 2006).

Implications for managers and policy makers 
From a managerial perspective, owners of small family firms must look at ways to balance the needs of their firm with the demands required from internationalisation. This may include owners and managers being open-minded enough to adapt existing familial norms and values to those necessary for successful internationalisation. Furthermore, owners and managers should also recognise that the decision to internationalise may itself affect the harmony of the family. Family owners should consider the inclusion of outsiders in order to broaden networks and enhance capabilities. If trust comes more readily from other family firms then pairing up with these firms as mentors/trainees may also be a way forward.

Policy makers need to also understand that internationalisation is a major challenge for small family firms. The resource requirements for evaluating, planning, and implementing internationalisation strategies may simply be too much for many of them. Nevertheless, providing such firms with resources in order to help develop more entrepreneurial environments may also not be sufficient. Instead, policy makers may also need to look at ways of changing existing mind-sets and practices, a in order for small family firms to make the best use of their limited resources. One way to do this would be for the investors to act as mentors to the businesses, sitting on boards and attending meetings regularly or by encouraging mentoring schemes with other similar businesses.

\section{Suggestions for future research}

We provide a starting point for future research into the internationalisation of small family firms. Given that this study focuses mainly on SEW factors that can promote or internationalisation, future research can be extended by looking at additional SEW factors not explored here or the social and cultural factors which may affect internationalisation (such as Confucian values). Additional areas related to the organisation and its environment could be the effect of changes in ownership and governance (different generations, the inclusion of nonfamily employees, the formation of trusts). Environmental factors like the pressures on the industry sector, the amount of innovation required, the nature of the home market may all have a significant part to play and are thus worthy of exploration. A comparative approach may also be interesting as it may highlight differences between family firms and non-family firms, Finally, from an organisational behaviour perspective it would be worth exploring the difference in trust 
relationships between and within families and outsiders and how this trust evolves during internationalisation.

\section{References}

Arregle JL, Naldi L, Nordqvist M and Hitt MA (2012) Internationalization of family-controlled firms: A study of the effects of external involvement in governance. Entrepreneurship Theory \& Practice 36:1115-1143.

Bell J, McNaughton R, Young S and Crick D (2003) Towards an integrative model of small firm internationalisation. Journal of International Entrepreneurship 1(4): 339-362.

Brouthers KD and Nakos, G (2004) SME entry mode choice and performance: A transaction cost perspective. Entrepreneurship, Theory \& Practice 28(3): 229-247.

Casillas JC and Acedo, FJ (2005). Internationalisation of Spanish family SMEs: An analysis of family involvement. International Journal of Globalisation and Small Business 1: 134-151.

Carr C and Bateman, S (2009) International strategy configurations of the world's top family firms. Management International Review, 49: 733-758.

Cerrato D and Piva M (2010) The internationalization of small and medium-sized enterprises: the effect of family management, human capital and foreign ownership. Journal of Management \& Governance 16: 617-644.

Chen M. (1994) Guanxi and the Chinese art of network building. New Asia Review Summer: 40

Chew R and Chew, S-B (2008) A study of SMEs in Singapore. Journal of Enterprising Communities: People and Places in the Global Economy 2(4): 332-347

Claver E, Rienda L and Quer D (2008) Family firms risk perception: Empirical evidence on the internationalization process. Journal of Small Business and Enterprise Development 15: 457-471.

Claver E, Rienda L and Quer D (2009) Family firms' international commitment: The influence of family-related factors. Family Business Review 22: 125-135.

Coviello, N (2006) The network dynamics of international new venture. Journal of International Business Studies 37(5): 713-731

Crick D and Jones MV (2000) Small high-technology firms and international high-technology markets. Journal of International Marketing 8(2): 63-85. 
De Massis A and Kotlar J (2014) The case study method in family business research: Guidelines for qualitative scholarship. Journal of Family Business Strategy 5(1): 15-29.

Donckels R and Fröhlich E (1991) Are family businesses really different? European Experiences from STRATOS”. Family Business Review 12(2): 146-160.

Ellis P (2000) Social ties and foreign market entry. Journal of International Business Studies 31(3): 443-469.

Erdener C and Shapiro DM (2005) The internationalization of Chinese family enterprises and Dunning's eclectic MNE paradigm. Management and Organization Review, 3: 411-436.

Eisenhardt K (1989) Building theories from case study research. Academy of Management Review 14(4): 32-50.

Fernández Z and Nieto, MJ (2005) Internationalization strategy of small and medium-sized family businesses: Some influential factors. Family Business Review, 18: 77-89.

Fernández Z and Nieto MJ (2006) Impact of ownership on the international involvement of SMEs. Journal of International Business Studies 37: 340-351.

Gallo MA and Pont, CG (1996) Important factors in family business internationalization. Family Business Review 9: 45-59.

Gallo MA and Sveen J (1991) Internationalizing the family business: Facilitating and restraining factors. Family Business Review 4 181-190.

George GJ, Wiklund and Zahra SA (2005) Ownership and the internationalization of small firms. Journal of Management 31: 210-233.

Gomez-Mejia LR, Makri M and Larraza-Quintana M (2010) Diversification decisions in familycontrolled firms. Journal of Management Studies 47: 223-252.

Graves C and Thomas J (2004) Internationalisation of the family business: A longitudinal perspective. International Journal of Globalisation and Small Business 1(1): 7-27.

Graves C and Thomas J (2006) Internationalization of Australian family businesses: A managerial capabilities perspective. Family Business Review 19: 207-224.

Graves C and Thomas J (2008) Determinants of the internationalization pathways of family firms: An examination of family influence. Family Business Review 21: 151-167.

Geringer JM, Tallman S and Olsen, DM (2000) Product and geographic diversification among Japanese multinational firms. Strategic Management Journal 21: 51-80. 
Hall A, Melin, L and Nordqvist M (2004) Entrepreneurship as radical change in the family business: Exploring the role of cultural patterns. Family Business Review 14(3): 193-208.

Hitt M, Hoskisson R and Ireland RD (1994) A mid-range theory of the interactive effects of international and product diversification on innovation and performance. Journal of Management 20: 297-326.

Javalgi RG, Todd P and Granot E (2011) The internationalization of Indian SMEs in B-to-B markets. Journal of Business \& Industrial Marketing 26: 542-548.

Johanson J and Mattsson LG (1988) Internationalisation in Industrial Systems - A Network Approach”, in Hood, N. and Vahlne, J.-E. (Ed.), Strategies in Global Competition, Croom Helm, London, 287-314.

Johanson J and Vahlne, JE (1977) The internationalization process of the firm: A model of knowledge development and increasing foreign market commitments. Journal of International Business Studies 8(1): 23-23.

Johanson J and Vahlne, JE (2009) The Uppsala internationalization process model revisited: From liability of foreignness to liability of outsidership. Journal of International Business Studies 40: 1411-1431.

Johanson J and Wiedersheim PF (1975) The internationalization of the firm: four Swedish cases. Journal of Management Studies 12(3): 305-322

Kets de Vries MFR (1985) The dark side of entrepreneurship. Harvard Business Review, 63: 160-167.

Köksal MH and Özgül E (2010) The export competitive advantages of Turkish manufacturing companies. Marketing Intelligence \& Planning 28(2): 206-222.

Kontinen T and Ojala A (2010a) The internationalization of family businesses: A review of extant research. Journal of Family Business Strategy 1: 97-107.

Kontinen T and Ojala A (2010b) Internationalization pathways of family SMEs: Psychic distance as a focal point. Journal of Small Business and Enterprise Development 17: 437-454.

Kontinen T and Ojala A (2011a) Network ties in the international opportunity recognition of family SMEs. International Business Review 20: 440-453.

Kontinen T and Ojala A (2011b) Social capital in relation to the foreign market entry and postentry operations of family SMEs. Journal of International Entrepreneurship 9: 133-151.

McConaughy D, Matthews C and Fialko A (2001) Founding family controlled firms: Performance, risk, and value. Journal of Small Business Management 39: 31-49. 
McDougall PP and Oviatt BM (2000) International entrepreneurship: The intersection of two paths. Guest editor’s introduction. Academy of Management Journal 43: 902-908.

Miles, MB and Huberman AM (1994) Qualitative data analysis: An expanded sourcebook. London, England: Sage.

Mustafa M and Chen S (2010) The strength of family networks in transnational immigrant entrepreneurship. Thunderbird International Business Review 52(2): 97-106.

Mustafa M, Ramos, HM and Chen S (2013) Internationalisation pathways of small Singaporean family firms: a socio-cultural perspective. International Journal of Globalisation and Small Business 5(4):

Ojala A and Tyrva inen P (2009) Impact of psychic distance to the internationalization behavior of knowledge-intensive SMEs. European Business Review 21(3): 263-77.

Oviatt BM and McDougall PP (1994) Toward a theory of international new ventures. Journal of International Business Studies 25(1): 45-64.

Oviatt, BM and McDougall, PP (1997) Challenges for Internationalization Process Theory: The Case of International New Ventures. Management International Review 37(2): 85-99.

Pinho JC (2007) The impact of ownership: Location-specific advantages and managerial characteristics on SME foreign entry mode choices. International Marketing Review, 24: 715-734.

Pukall TJ and Calabrò A (2013) The Internationalization of Family Firms: A Critical Review and Integrative Model. Family Business Review XX(X), 1-23

Ruzzier M, Hisrich, RD and Antoncic B (2006) SME internationalization research: past, present, and future. Journal of Small Business and Enterprise Development 13(4): 476-97.

Sciascia S, Mazzola P, Astrachan, JH and Pieper TM (2012). The role of family ownership in international entrepreneurship: Exploring nonlinear effects. Small Business Economics 38(1): 15-31.

Sim AB. (2006). Internationalization strategies of emerging Asian MNEs-case study evidence on Singaporean and Malaysian firms. Asia Pacific Business Review 12(4): 487-505.

Sapienza P, Zingales, L and Guiso L (2006) Does culture affect economic outcomes? (No. w11999). National Bureau of Economic Research.

Tan WL and Fock ST (2001) Coping with growth transitions: The case of Chinese family businesses in Singapore. Family Business Review 14(2): 123-139. 
Thornton PH, Ribeiro-Soriano D and Urbano D (2011) Socio-cultural factors and entrepreneurial activity: An overview. International Small Business Journal 29(2): 105-118.

Tsang EWK (2002) Learning from overseas venturing experience: the case of Chinese family businesses. Journal of Business Venturing 17: 21-40.

Tsang EWK (2001) Internationalizing the family firm: a case study of a Chinese family business. Journal of Small Business Management 39(1): 88-94.

Tsui-Auch LS (2004). The professionally managed family-ruled enterprise: ethnic Chinese business in Singapore. Journal of Management Studies 41: 693-723.

Yeung HWC (2006). Change and continuity in Southeast Asian ethnic Chinese business. Asia Pacific Journal of Management 23: 229-54.

Yeung HWC (2004) Chinese Capitalism in a Global Era: Towards Hybrid Capitalism.

Routledge, New York, NY.

Yeung HWC (1999) The internationalization of ethnic Chinese business firms from Southeast Asia: strategies, processes and competitive advantage. International Journal of Urban and Regional Research 23(1): 82-102

Yin RK (2003) Case study research: Design and methods. Applied Social Science Method Series (3rd ed., Vol. 5). Thousand Oaks, CA: Sage.

Zahra SA (2003) International expansion of U.S. manufacturing family businesses: The effect of ownership and involvement. Journal of Business Venturing 18: 495-512.

Zahra SA, Hayton JC, Neubaum DO, Dibrell and Craig J (2008) Culture of family commitment and strategic flexibility: The moderating effect of stewardship. Entrepreneurship Theory and Practice 32: 1035-1054.

Zhou L, Wu WP and Luo, X (2007) Internationalization and the performance of born-global SMEs: the mediating role of social networks. Journal of International Business Studies 38(4): 673-690. 
Table 1: Key Characteristics of Case Firms

\begin{tabular}{|c|c|c|c|c|}
\hline Firm & $\begin{array}{l}\text { Year Founded/ first } \\
\text { internationalisation }\end{array}$ & Ownership structure and \% & $\begin{array}{l}\text { First International Market } \\
\text { Served/(Additional markets) }\end{array}$ & Industry \\
\hline A & 1966/1984 & $\begin{array}{l}\text { Highly fragmented, } 55 \% \text { founding } \\
\text { family, } 45 \% \text { extended family }\end{array}$ & Malaysia(Indonesia) & Outdoor and Industrial Manufacturing \\
\hline B & $1972 / 1993$ & $\begin{array}{l}\text { fragmentised, } 65 \% \text { founding family, } \\
20 \% \text { siblings, } 15 \% \text { extended family }\end{array}$ & $\begin{array}{l}\text { Malaysia and Indonesia (Brunei, } \\
\text { Thailand) }\end{array}$ & Light Automation Manufacturing \\
\hline C & $1985 / 2000$ & $\begin{array}{l}\text { Highly fragmented, } 40 \% \text { founding } \\
\text { family, } 60 \% \text { cousins etc }\end{array}$ & $\begin{array}{l}\text { Taiwan (Malaysia, Thailand, } \\
\text { Philippines) }\end{array}$ & $\begin{array}{l}\text { F\&B Sales/Distribution and Light F\&B } \\
\text { Manufacturing }\end{array}$ \\
\hline D & $1986 / 2003$ & $\begin{array}{l}\text { Unified, } 70 \% \text { founding and } \\
\text { extended family, } 30 \% \text { non-family } \\
\text { member }\end{array}$ & $\begin{array}{l}\text { Malaysia and Brunei (Australia, Nez } \\
\text { Zealand, Vietnam, Laos, China) }\end{array}$ & $\begin{array}{l}\text { Immigration and International Manpower } \\
\text { Services }\end{array}$ \\
\hline $\mathbf{E}$ & $1996 / 2006$ & $\begin{array}{l}\text { Highly fragmented among various } \\
\text { family groups, } 40 \% \text { founding, } 30 \% \\
\text { extended family, } 30 \% \text { through } \\
\text { marriage to extended family }\end{array}$ & $\begin{array}{l}\text { Malaysia (Vietnam, Thailand, } \\
\text { Indonesia }\end{array}$ & IT services development \\
\hline $\mathbf{F}$ & $1993 / 2005$ & $\begin{array}{l}\text { Unified, } 65 \% \text { founding family, } 30 \% \\
\text { non-family partners, } 5 \% \text { extended } \\
\text { family }\end{array}$ & $\begin{array}{l}\text { Indonesia ( Qatar, UAE, Yemen, } \\
\text { Malaysia, USA,Thailand }\end{array}$ & $\begin{array}{l}\text { Food and beverage production and } \\
\text { distribution }\end{array}$ \\
\hline
\end{tabular}


Table 2: Internationalisation behaviour of case firms

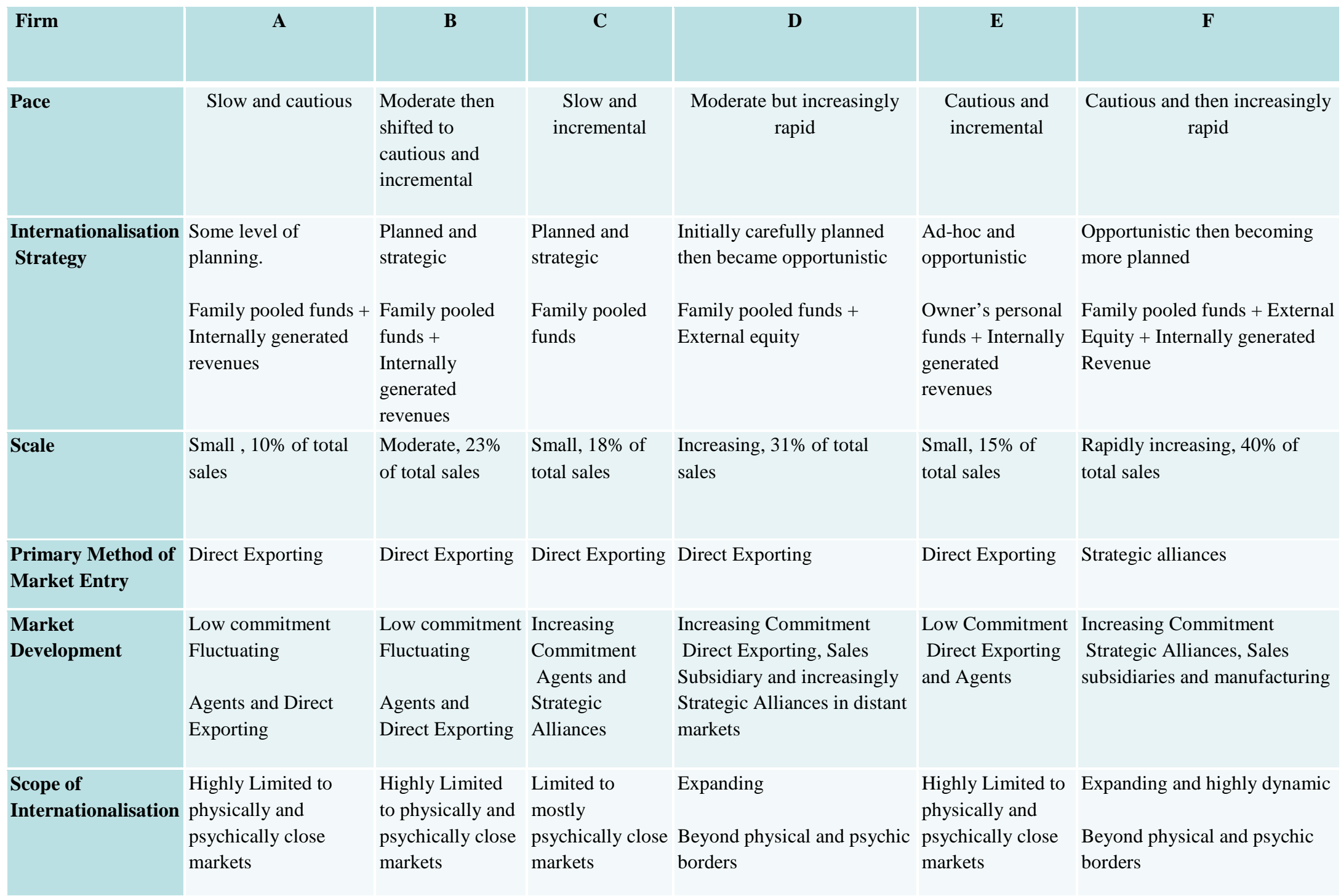


Table 3: Summary of Factor Effects

\begin{tabular}{|l|l|}
\hline Factor & Effect on Internationalisation \\
\hline Harmony & $\begin{array}{l}\text { - The desire to maintain harmony inhibits efforts to internationalise. Conflict can } \\
\text { result in a loss of human and financial capital. }\end{array}$ \\
\hline Trust & $\begin{array}{l}\text { + Positive influence on initial internationalization through trusted family agents } \\
\text { (exports). (Uppsala steps 1 and 2). } \\
\text { - Lack of trust in 'outsiders' limits the expansion of the internationalisation } \\
\text { process beyond due to lack of trust. (Uppsala steps } 3 \text { and } 4 \text { more difficult). }\end{array}$ \\
\hline Networks & $\begin{array}{l}\text { - Small family firms are insular, restricting themselves to a narrow set of social } \\
\text { and business contacts. Networks are built on trust which are limited to family, } \\
\text { close friends and close business associates or other small family firms. True } \\
\text { internationalization is limited (Uppsala steps 1 and } 2 \text { only). }\end{array}$ \\
\hline Resource and Capability & $\begin{array}{l}\text { - Limited trust, small networks, desire for harmony results in limited resources } \\
\text { and thus limited ability to internationalise beyond a basic level (Uppsala steps } 1 \\
\text { and 2 only). }\end{array}$ \\
\hline
\end{tabular}


Figure 1. The Relationship between harmony, trust, networks, resources/capabilities and internationalisation

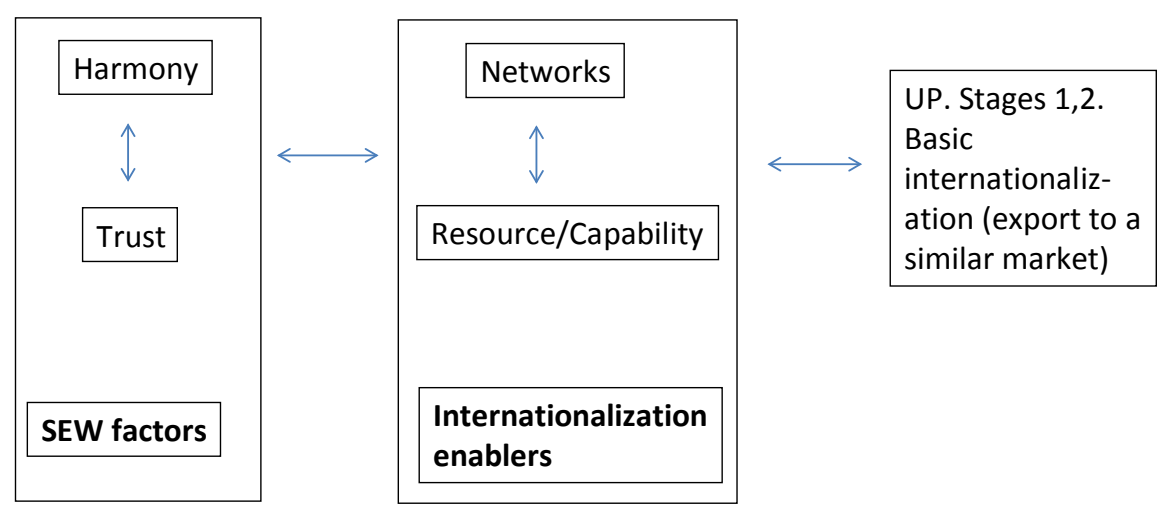

UP. Stage 1,2.
Basic
internationaliz-
ation (export
to a similar
market)

UP. Stage 3,4.

More extensive

Less emphasis on trust internationalization (joint ventures, different markets)

UP = Uppsala model of internatonalization (Johanson and Valne, 2009) 